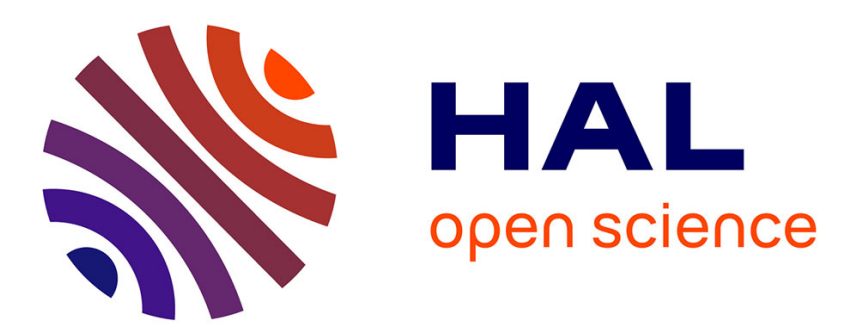

\title{
Firing at the Clocks: Cinema, Sampling, and the Cultural Logic of the Late Capitalist Artwork
}

\author{
Martine Beugnet
}

\section{To cite this version:}

Martine Beugnet. Firing at the Clocks: Cinema, Sampling, and the Cultural Logic of the Late Capitalist Artwork. Framework, The Journal of Cinema and Media , 2013, 54 (2), pp.192. 10.13110/framework.54.2.0192 . hal-02919616

\section{HAL Id: hal-02919616 \\ https://hal-univ-paris.archives-ouvertes.fr/hal-02919616}

Submitted on 23 Aug 2020

HAL is a multi-disciplinary open access archive for the deposit and dissemination of scientific research documents, whether they are published or not. The documents may come from teaching and research institutions in France or abroad, or from public or private research centers.
L'archive ouverte pluridisciplinaire HAL, est destinée au dépôt et à la diffusion de documents scientifiques de niveau recherche, publiés ou non, émanant des établissements d'enseignement et de recherche français ou étrangers, des laboratoires publics ou privés. 


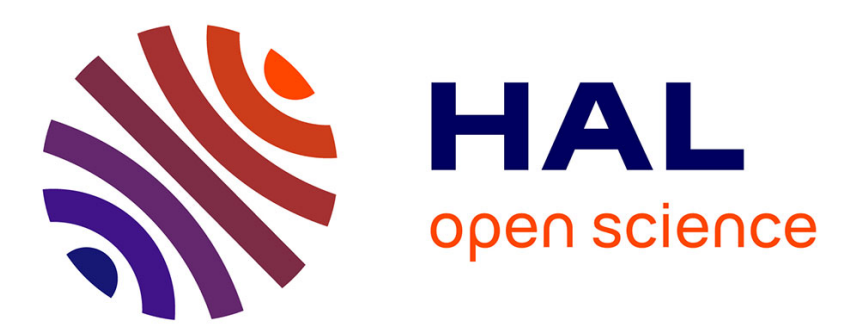

\title{
Firing at the Clocks: Cinema, Sampling, and the Cultural Logic of the Late Capitalist Artwork
}

\author{
Martine Beugnet
}

\section{To cite this version:}

Martine Beugnet. Firing at the Clocks: Cinema, Sampling, and the Cultural Logic of the Late Capitalist Artwork. Framework, The Journal of Cinema and Media , 2013, 54 (2), pp.192. 10.13110/framework.54.2.0192 . hal-02919616

\section{HAL Id: hal-02919616 \\ https://hal-univ-paris.archives-ouvertes.fr/hal-02919616}

Submitted on 23 Aug 2020

HAL is a multi-disciplinary open access archive for the deposit and dissemination of scientific research documents, whether they are published or not. The documents may come from teaching and research institutions in France or abroad, or from public or private research centers.
L'archive ouverte pluridisciplinaire HAL, est destinée au dépôt et à la diffusion de documents scientifiques de niveau recherche, publiés ou non, émanant des établissements d'enseignement et de recherche français ou étrangers, des laboratoires publics ou privés. 


\title{
Firing at the Clocks: Cinema, Sampling, and the Cultural Logic of the Late Capitalist Artwork
}

\author{
Martine Beugnet
}

In his writing about the medium of the moving image, Walter Benjamin classically emphasized film's role as modern man's perceptual training tool, one that was uniquely apt to mediate, through its form as well as its apparatus, the intensified rhythm and shock of an era of accelerated industrialization and urbanization. ${ }^{\mathrm{I}}$ Hence for the cultural historian and philosopher, the study of film offered key clues for an understanding of the construction of the modern self, its relation to time, and, broadly speaking, art's contribution to a modern sense of identity and history-all areas of reflection that remain at the forefront of new media theory. As Peter Osborne sums it:

Film is, famously, the technology for representation most closely associated with philosophical insight into the mutual and paradoxical constitution of time and the self. For Benjamin, it was the medium in relation to which "all problems of contemporary art find their definitive formulation."

Today, Osborne adds, cinema's legacy is in evidence in the practice of contemporary artists who, aided by digital technology, are appropriating and manipulating the moving image archive as well as cinema's techniques and spectatorial apparatus, in what he describes as "a general experimental articulation of technologies of perception and patterns of artistic and social use."3

Indeed, in the views of a number of contemporary art historians and art practitioners, the widespread vogue for found footage techniques is one of the ways in which the older medium of cinema is being offered a new lease on life in 
the museum and gallery. ${ }^{4}$ Conversely, one may concur with Philippe Dubois and argue that in effect, it is cinema-its techniques, aesthetics, perceptual regime, and historical records-that impregnates the art world, opening new avenues for experimentation and self-reflection in moving-image-based art and art theory. Dubois calls this phenomenon the "effet cinéma." "Diversified and multiform," the "cinema effect" can be felt in all areas of contemporary art-institutional, artistic, and theoretical—where cinema now "informs, feeds, influences, works through, inspires and irrigates" artists' and curators' practices. ${ }^{5}$

Appearing at the uncertain junction between appropriation and creative hybridization, Christian Marclay's 2010 video work, The Clock, the most popular example of the widespread practice of artists' found footage assemblage to date, arguably stands as an exemplary instance of the way contemporary artists sift through the moving image archive in an attempt to offer new insights on the correlation between art, time, and perception.

The work's initial conceit, realized thanks to the storing and editing capacities afforded by digital technology and with the help of a team of assistants, was very simple: thousands of film excerpts, all evoking the passage of time, edited together into a twenty-four-hour video fully synchronized with actual, non-diegetic time. The piece is effectively a clock, and the viewers' first gratification, even before they reach the room where the work is on display, lies with the realization of Marclay's simple and clever premise.

Selected from hundreds of films as well as a number of made-for-TV features, the extracts are mostly very brief and around the time of each hour, the pace quickens as the choice of images builds into a more emphatic sense of suspense. Whereas artists such as Douglas Gordon famously explored duration through the slowing down of cinematic flow almost to the point of stillness, Marclay resorts to quick cutting instead, assembling thousands of fragments that unravel in rapid succession, literally forsaking duration in favour of time-as-movement.

We may be captivated by it or remain immune to its attractions, but there is no denying that The Clock raises troubling questions about the relationship between cinema and the art world — and, more broadly, in the way Marclay's piece harnesses mechanical time and the montage technique to its closed formal system, about art and commodification. Indeed, part of the fascination exercised by The Clock rests with the polarized reactions it generates, whether the piece is envisaged as a kind of "imaginary museum" in celebration of cinema and the "effet cinéma" or, alternatively, as a virtual mausoleum to the medium of the moving image that reduces the montage effect to an easily consumed serial form.

In this article, Marclay's method is first explored in the light of the tradition of moving image compilation in which filmmakers and artists have been taking on the role of curators. Marclay's serial sampling is further considered in relation 


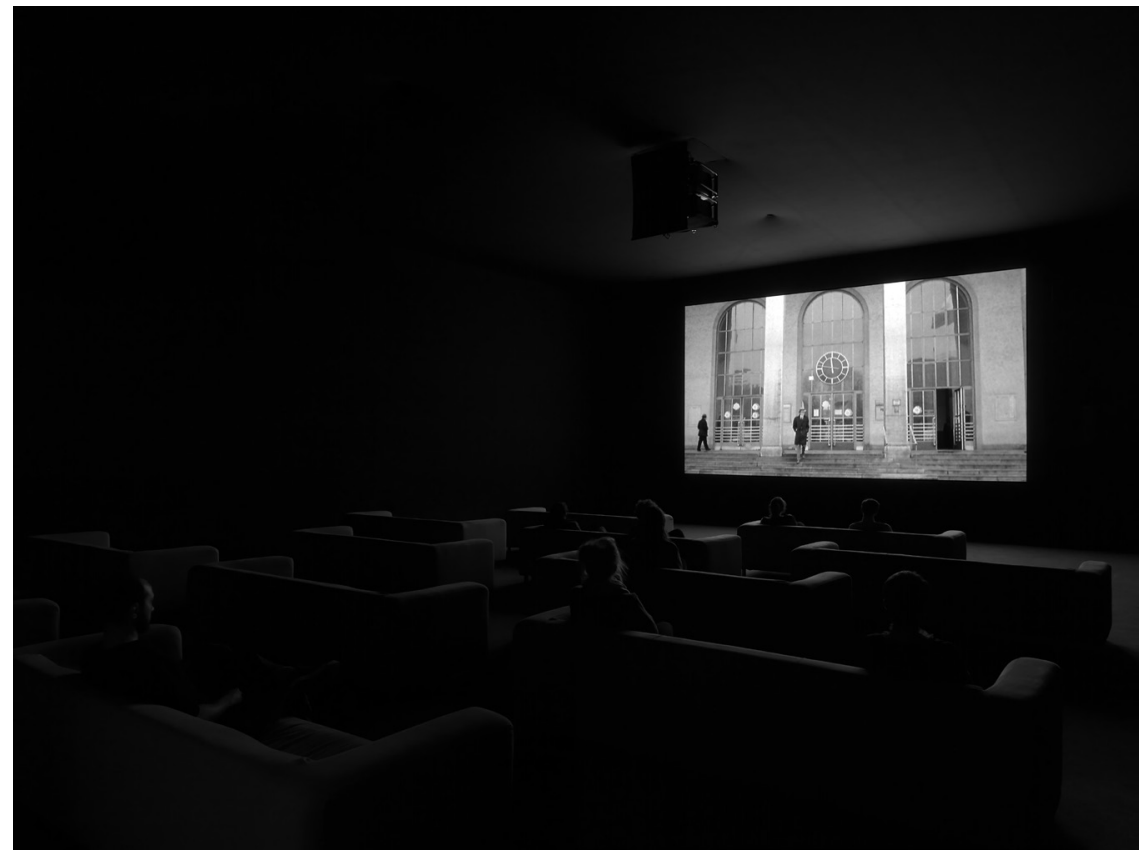

Figure 1. Christian Marclay, installation view of The Clock (2010). Single-channel video with sound; 24 hours. White Cube Mason's Yard, London (October 15-November 13, 2010) @ Christian Marclay. Courtesy Paula Cooper Gallery, New York and White Cube, London. Photo: Todd-White Photography.

to the emergence of an "ethics" of appropriation as suggested by the writings of Hal Foster, Emma Cocker, and Jan Verwoert. It is finally discussed in terms of spectatorial experience and the "museification" (or, indeed, the mu(seu) mmification) of cinema.

Crucial to the argument developed here is the recognizance that Marclay's video experiment in time and history cannot be dissociated from its context of production and dissemination. In the way it makes industrial rhythms of production and consumption integral to its form and mode of display, The Clock thus arguably reflects and participates in the continuing interpenetration of art and capitalist culture.

By extension, Marclay's use of found footage and of cinematic techniques conjures up an issue that is often overlooked in relation to the status of the medium of the moving image in the art world: the question of cinema's modernist legacy. In what form and to what extent is film's past as well as its future as a radical form of artistic practice continued in experimental filmmaking, present and acknowledged in contemporary works exhibited in galleries and museums? 
Moreover, The Clock is staged in the form of a dispositif destined for gallery and museum exhibition, yet simulating conditions of theatrical or home cinema reception as part of its mise en sceine. Marclay's work thus conjures up the debate about cinema and television's afterlife in the era of the digital and of media convergence, and their relation both to video art and artists' films and to art institutions. As a fully functional clock, it not only throws into relief issues of the quality of gallery spectatorship, but raises questions about the status and meaning of the moving image-cum-art object, as well as the classic association of cinema's beginnings with the establishment of modern time-or, to be precise, of the (universalized) Western clock.

\section{Borrowing from the Moving Image Archive}

In an often-quoted passage of his thesis on history, Walter Benjamin recounts how, on the first day of the 1848 revolution, "the clock-towers were shot at independently and simultaneously in several places in Paris." Benjamin mentions this as one example of a collective desire to blow up what he calls "the continuum of history," to break away from the official, chronological history and seek out an alternative version, one that would account for progress' wreckage and the existence of the exploited and outcast. ${ }^{6}$ It follows that for Benjamin the modern historian should take the role of a scavenger-or, as Béatrice Hanssen summarises it, "the rag picker and garbage collector of history ... who seeks his material and inspiration not in culture's officially sanctioned venues but in the refuse and debris that has been overlooked, repressed or marginalized." This debris is to be assembled into a "new constellation" through "strategic poetic montage."7

As the centrality of the term montage suggests, and as the work of avantgarde filmmakers as well as film essayists has demonstrated, the medium of film, although dependent on a linear unfolding of images and sounds, is particularly apt to serve such strategies: through editing, moving-image-based media can defeat spatial and temporal divides, bring together heterogeneous material, and create a polyphony of voices and points of view. It can thus serve the aims of the "imaginary museum" 8 - though, in contrast with André Malraux's project, by bringing references to contexts of production into play, cinema can create imaginary museums that do not consign art works to a transcendental realm of pure form. ${ }^{9}$

In the introduction to his 1964 book Films Beget Films, Jay Leyda points out that compilation and montage techniques and the reuse of footage in general, diversely practiced by experimental filmmakers as well as essayists and documentarists, are almost as old as cinema itself. ${ }^{10}$ From the 1970 onwards, however, video artists also started to exploit the film archive, sampling and 
compiling alternative histories of narrative cinema. In the wake of the digital shift and of film's pronounced obsolescence, the art world's interest in film increased, and the field of video art was seized by an archival and curatorial impulse that led to a new flourishing of found footage techniques. ${ }^{\text {II }}$ In video art as in film, the sifting, selecting and compiling of found footage is akin to a form of curatorial process that reflects on the history, evolution, and future of the moving image. A few examples come to mind in relation to the unusual scope of Marclay's project: Jean-Luc Godard's all-embracing video project Histoire(s) du Cinéma (FR, 1998), Gustav Deutsch's early film typologies (Film ist, AT, 1996-2002), Thom Andersen's comprehensive portrait of Los Angeles, Los Angeles Plays Itself(US, 2003), and Claudio Pazienza's poetic tour of a film archive, the award-winning Archipels Nitrate (BE, 2010).

In contrast with Godard's densely intertextual audiovisual collage, Deutsch's idiosyncratic collections, Pazienza's free associative combinations, and Andersen's opinionated montage of contrasted extracts, however, Marclay champions a specific kind of "serial sampling" method where brief fragments are selected and compiled based on their graphic or thematic similarity. The technique has been used to great analytical effect by a number of film and video makers in the recent past: by American video artist George Barber, for instance, who combines serial compilation with scratch montage to deconstruct mainstream narratives, as well as exponents of the contemporary Austrian school of experimental film and video-Matthias Müller, Claude Girardet, Pierre Tscherkassky—whose work relentlessly probes the violent, compulsive unconscious of classic Hollywood cinema. ${ }^{\mathrm{I2}}$ Similarly, Australian multimedia artist Tracey Moffatt's serial compilations offer chilling explorations of mainstream cinema's legacy of explicit and implicit sexism and racism. ${ }^{13}$

These works are typical, however, of the dominant trend in found footage compilation work destined for the gallery, in that the range of the raw material tends to be of a limited kind. Even when artists espouse experimental techniques, the main focus is likely to be on classic cinema, more easily deconstructed, with some more marginal interest in the work of the so-called cinema auteurs. As Philip Monk has remarked, contemporary artists tend to make a type of "experimental film from the resources of popular entertainment." ${ }^{44}$ Yet the focus on (deconstructing) cinema as entertainment means that in the space of the modern art museum or gallery, the revisiting of cinema as a medium of the past arguably gives rise to a kind of selective history. The great absent tends to be experimental cinema, rendered doubly invisible in that it rarely appears as actual content, but also because in some cases techniques and experiments that are inherent to the practice of experimental filmmaking are seemingly reinvented anew in the context of the gallery. 
Advertised as a work of compilation on a scale so far unknown, The Clock is, by extension, presented as a kind of journey through the history of the moving image in twenty-four hours. ${ }^{\text {Is }}$ This a-chronological overview initially appears both inclusive and non-elitist: the compilation calls on the viewer's memory of cinema and television while seemingly creating a platform where classic and unknown works of all genres and forms can meet on an equal footing.

In effect, in the hours I sat through the screening, and through the night, when the piece became more interesting and strange (with excerpts from horror flicks and soft porn movies and episodes where inactivity seemingly becomes the main subject matter), ${ }^{16}$ a selective history of the moving image emerged in which classic western narrative cinema and, to a lesser extent, western television fiction were largely dominant. For some observers, The Clock might well stand as the quintessence of the Bergsonian nightmare, but many a reviewer has praised the way it explores cinema's multifaceted relation to time. ${ }^{17}$ For Sight and Sound critic Jonathan Romney, the work holds "considerable philosophical density" and encourages us to "examine the way time-or the effect of time-is created in film." ${ }^{8}$ Romney offers one of the few reviews that have commented on The Clock's characteristic "western" slant-an observation that his article does not extend, however, to the specific concept of time exemplified by Marclay's piece.

\section{Art, Chronotechnology and (Resistance to) Commodification}

In an interview with Romney, Marclay explained that it had proved difficult to find, for instance, Bollywood films featuring clocks. ${ }^{19}$ In effect, The Clock's specific take on the moving image archive extends to the way it implicitly evokes the pre-eminence of a global western time. As such, The Clock forms an interesting contrast to the recent work of South African artist William Kentridge. In The Refusal of Time (ZA, 2012), Kentridge combines film and displays of historical machinery for measuring time to look at the universalization of the western clock that underpinned the colonial project. The Refusal of Time takes the form of a complex assemblage of heterogeneous artifacts and moving images where the carnivalesque nature of the films works to disturb the would-be scientific discourses embodied in the machinery.

Marclay's project can also be compared with a film that belongs to a very different moving image world yet is equally concerned with issues of art and time: Agnès Varda's Les Glaneurs et la glaneuse/The Gleaners and I (FR, 2000). Close to Benjamin's description of the historian as a rag picker, in this film Varda posits herself as a gleaner who records and salvages unwanted shreds of pro-filmic reality. Varda's film offers a persuasive and imaginative critique of commodity culture, combined with a reflection on time and on the tyranny of accelerated industrial 
rhythms of production and consumption that determine the ever-briefer lifespan of objects and practices, as well as people as valuable assets in a late capitalist culture. In a sequence at a street market, Varda salvages a clock without hands that she then proudly displays on her mantelpiece.

In "The Western Hour," Sylviane Agacinski emphasizes the import of artistic strategies aimed at undermining the hidden and pervasive effect of globalized time. She reminds us that

Globalization is the unification of the world's rhythms, all adjusted to the Western clock, that is, to contemporary chronotechnology ... The technical hegemony of the West expresses itself all over the world through the extension of production methods and the establishment of its temporal architecture. But it is not only the measure of time that has been unified; it is also its value, reduced to market value of work time. ${ }^{20}$

Mary Ann Doane's The Emergence of Cinematic Time looks more specifically at the advent of cinema in relation to the contemporary and systematic rationalization of time that was characteristic of industrialization and, more generally, capitalism. ${ }^{21}$ Cinema, she argues, held an ambivalent part in this process: whilst in cinematic forms of storytelling the arbitrariness of modern life was contained and tamed in the shape of linear causality, alternative film aesthetics, such as those explored by art and avant-garde filmmakers, would point to the possibility of a resistance to rationalization.

From the vantage point of the early twenty-first century, Marclay's piece arguably recalls cinema's ambivalent legacy. Whilst it evidently plays on the classic association of cinema's beginnings with the establishment of modern, industrial time, the sampling method seems to both playfully celebrate cinema as one expression of the homogenizing force of modern, global time while also demonstrating, through the apparent heterogeneity of its sources, the impossibility of containing contingency. By the same token, however, what it also points to is how once radical techniques, such as non-narrative montage, become absorbed in commodity culture.

The Clock is intriguing and seductive in the way it recreates film as one entirely porous spatial and temporal ensemble through which objects, actors and characters can seemingly travel, appear, and reappear, and, in the case of certain actors, age and regain their youth in the space of a few minutes or hours. The editing has been repeatedly described as virtuoso work, and the result reminds us of Marclay's musical background and long-lasting engagement with the rhythmical qualities of the medium of the moving image. Sound bleeds over one fragment to the next; gestures, camera movements, and compositions echo one another 
across cuts; and the shots are seamlessly linked into an illusory continuity that plays fully on the Kuleshov effect: we see clocks, then characters from different movies apparently watching them; we see people running on a train platform and catching a train in a station figuring in another feature, in a different place and a different period, and so on.

At the same time, however, by virtue of its precise formal principle, The Clock appears curiously old fashioned. With its relentless fragmentation, its precise taxonomy, the connection it creates between film and the mechanical, it seems to hark back to film's beginnings, the early cinema of attraction, when the medium of the moving image was considered emblematic in its evocation of modern perception, modern life, industrial rhythms, and the assembly line. The press releases and the trailer emphasize Marclay's reliance on the latest (digital) technology, the employment of a team of half a dozen researchers for this project as well as the sheer number of extracts and the lengthy, labor-intensive task of editing the fragments: in other words, the piece is advertised very much as an attraction, a "novelty," which value can be appreciated and measured in relation to its mode of production and spectacular technical achievements. ${ }^{22}$

The success of Marclay's The Clock rests with its astute combination of form and content, the transformation of the artwork, by way of the medium associated with modern time, into the very artifact that has come to represent the measure of time. By the same token, The Clock both reflects on and partakes of the kind of commodification process that underpins the unification of the concept of time and the collapsing together of work and leisure time described by Agacinski. Indeed, in The Clock montage itself is arguably transformed into a simple, infinitely reproducible meta-system, a serial form that neatly replicates common operations of commodification and rationalization and, by virtue of its strict taxonomy, contains the possibility of contingency offered by the multiplicity of its sources.

In The Clock, each sample is replaceable (by another extract showing a similar time), de-contextualised, emptied of its meaning, and made exchangeable for another: the compilation combines the effect of serialization with the reduction of a great variety of data into a homogeneous whole, its taxonomy itself dependent on the kind of inanimate object that is a natural material extension of the modern commodification of time and space. As such, Marclay's serial sampling has affinities with familiar manipulations of moving image data, including certain advertising practices. ${ }^{23}$ (We may recall that in 2007 Apple seized on the idea for Marclay's 1995 video, Telephones (US/UK), a compilation of extracts from classic film scenes with telephones, and turned it into an advertisement for the iPhone). ${ }^{24}$ The Clock's access to "genuine cross-over status, becoming popular beyond the art world," ${ }^{25}$ and its success in attracting the attention and capital of well-known 
international art institutions, may be related to its compelling bridging of once radical montage forms with everyday practices of serial compilation characteristic of today's capitalist visual economy. ${ }^{26}$

\section{Time, the Moving Image, and the Museum}

The prominent place readily granted to Marclay's oeuvre by the world's most established museums, combined with the piece's emphasis on fragmentation and speed, brings to mind the opening sequence of Varda's The Gleaners. The film starts with a journey to the museum of Orsay, a sequence that opens with a shot of the building's frontage with its large clock, a reminder that before it became a museum Orsay was a train station-a building that stood as the very emblem of industrial modernity. Yet it is in Orsay that Varda finds Millet's Glaneuses (I857), arguably the most famous depiction of a practice, gleaning, that mechanization and the rationalization of modes of production destined to obsolescence. The combination of post-industrial museum space and classic realist painting is Varda's cue to a brief, humorous comment on contemporary modes of artistic consumption. Following from the prominent shot of the Orsay clock, Varda resorts to a speeded up effect to emphasize the superficial engagement of viewers with the painting. Most visitors barely take the time to have their photo taken in front of the masterpiece before moving on to the next display. The sequence thus offers itself as a witty stab at the kind of cultural consumerism described by Steven Jacobs, where present day museums become "machines designed for the quick and efficient circulation of large numbers of visitors." ${ }^{27}$

With The Clock, Marclay brings clock time inside the contemporary museum (whose sparred down facades rarely bear such functional displays as clocks), using the cinema dispositif as his Trojan horse at it were. Indeed, the work negotiates the vexed issue of the viewing conditions of time-based works in the gallery and museum in a fascinating manner.

In the now classic debate on absorption-versus-distracted reception, the modes of display characteristic to the gallery or museum space were initially presented as a productive alternative to cinema's traditional dispositif. Where conventional cinema had seemingly betrayed the consciousness-raising potential that the early theorists had associated with the medium of the moving image, video art appeared as an antidote, its reception in galleries and museums comparing positively to the absorbed-read: passive-experience offered to spectators through the theatrical release of classic feature films. As Catherine Fowler summed it up, having escaped from the cinema auditorium, the moving image could now invite "responses from its spectators that are far from the passive, distanced stance of the auditorium.. ${ }^{28}$ Catherine Elwes similarly emphasized the newly acquired 


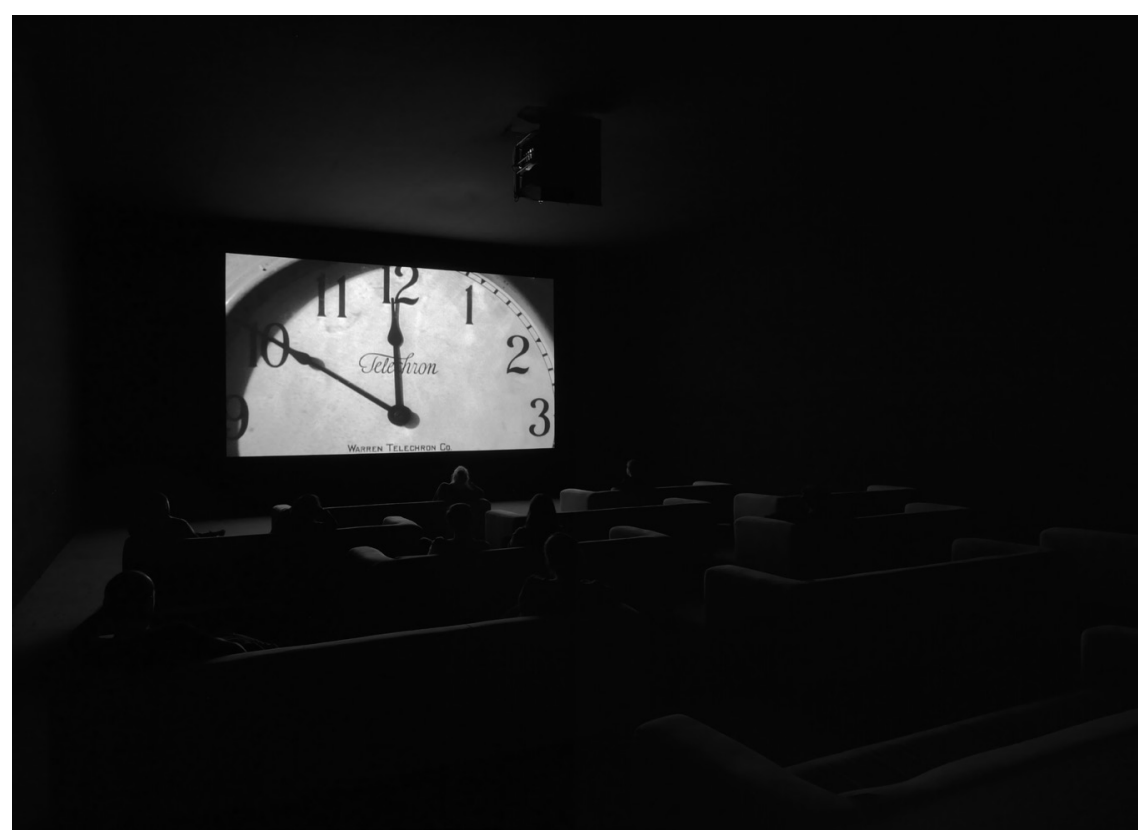

Figure 2. Christian Marclay, installation view of The Clock (2010). Single-channel video with sound; 24 hours. White Cube Mason's Yard, London (October 15-November 13, 2010) (c) Christian Marclay. Courtesy Paula Cooper Gallery, New York and White Cube, London. Photo: Todd-White Photography.

freedom of the spectator "no longer constrained by cinema schedules" and "free to determine the length of exposure to the images." 29

Conversely, however, nuanced descriptions of the experience of cinema viewing have been offered, ${ }^{\circ}$ and questions have been raised about the material conditions of cinema's entry into the museum. Here, arguments often focus on the quality of audience reception in gallery spaces, equating it less with an active, critical engagement than with a form of highbrow window shopping, channel surfing, or browsing. Writing about his experience of moving image works in the gallery, filmmaker and writer Mike Hoolboom describes the spectatorial involvement with moving image works in characteristically unconvinced terms:

The biggest difference between the movie theatre and gallery is the shared look. In the gallery people come and go, sampling the buffet, watching parts of some things, ignoring others completely, looking at moments again and again. But mostly browsing. There is no browsing in the movie theatre, in the gallery the shopping (do I like this? Is it me?) never has to end. ${ }^{31}$

The Clock gives an interesting spin to the debate on spectatorial engagement both 
in its manipulation of suspense effects and in the way it duplicates and adapts the traditional cinema viewing conditions.

The Clock is normally displayed in a large, darkened room, with comfortable seating so as to encourage the viewer to settle: a series of small sofas are arranged in neat rows so as to constitute a kind of cross between film theater and homeviewing. Because the film itself is effectively a clock, however, the spectators are, at all times, aware of the time they pass in front of the screen, and indeed remain connected to and conscious of the non-diegetic present thanks to the synchronization between diegetic and extra-diegetic time. Hence, many a visitor tends to leave the room on the hour or on the half hour.

The accumulation of brief extracts, on the other hand, can keep the spectator spellbound by appealing to her memory in a quiz-like mode-not only "What happens next?" but also "What film did this extract come from and what might the next extract be?"32 Most effectively, the work plays fully on the effect of suspense emphasized by the ubiquitous presence of the clock, so that "the plot gears itself into that of the film clips he uses, in which characters anticipate a catastrophe that will be unleashed at a certain moment: a bomb's explosion, a missile's strike." ${ }_{33}$

Rosalind Krauss further compares the addictive quality of Marclay's editing to the Althusserian power of interpellation:

The Clock's synch-time joins audience and screen in the manner of what film scholars call interpellation, after Althusser's "Ideological State Apparatuses," as the subject "recognizes" himself as the addressee of a command, thus identifying with the commander, himself.34

Ultimately, Krauss concludes, The Clock is a masterly play on suspense, the illusion of self-presence and the dilatation of the "now effect." Mention of Althusser calls for an alternative interpretation, however, based on the classic association of Althusserian interpellation with advertising tactics. As in the earlier discussion of the serial sampling method, it is indeed tempting to associate the addictive power of The Clock's endlessly shifting fragments with Marclay's ability to make the gallery "browsing" or "shopping" described by Hoolboom an integral, built-in ingredient of the experience of watching The Clock.

\section{Conclusion}

As Rosalind Krauss reminds us in her classic description of the museum as a latecapitalist institution, Adorno expressed doubts about Benjamin's description of the rag-picker as a radical figure, pointing out Benjamin's failure to acknowledge the capitalist function of the rag-picker who reintroduces that which he scavenges 
back into the commercial system of exchange value. 35 Though in more recent writing Krauss herself sees in Marclay's work the signs of the emergence of a new vanguard, ${ }^{36}$ The Clock certainly raises issues in relation to the ways in which cinema's legacy, in the form of archive as well as techniques and aesthetics, is recycled by the art world. Experimental films destined for theatrical release and artists' films produced for galleries and museums are, as Jonathan Walley demonstrated, ${ }^{37}$ created according to contrasted modes of production and distribution (in the case of the artists' films, the practice of editioning the work to raise its value) that make it difficult for the latter to avoid the logic of capitalist recuperation signalled by Adorno. Further than the context of production however, or as an extension of it, divergent approaches to appropriation and montage also emerge here.

Taking her cue from Hal Foster's discussion of techniques associated with appropriation,,$^{38}$ Emma Cocker emphasizes how

borrowing from the archive can be interpreted ... as a specific tactic for resisting and responding to the pressures and accelerated temporalities of late capitalism, and the dislocation (from both present and past) experienced by the individual in relation to the global and increasingly virtual context in which they are expected to perform. ${ }^{39}$

In a similar vein, Jan Verwoert argues that given the "undiminished if not increased power of capitalist commodity culture to determine the shape of our daily reality, appropriation is a way of cutting a slice out of the substance of this commodity culture to expose the structures that shape it,' freeing that slice of material culture from the grip of its dominant logic and put[ting] it at the disposal of a different use." 40

These comments on the topical critical import of practices that engage with the appropriation and compilation of existing material seem particularly apposite in the context of the growing popularity of found footage techniques in recent video art. As Marclay's practice demonstrates, however, the critical and subversive potential emphasized by Cocker and Verwoert needs to be considered in relation to the specificity-in aesthetic, historical, and economic terms-of the space provided by art institutions.

There is no denying the pleasures to be derived from The Clock's formal achievements. Yet there is also, arguably, something deadly about Marclay's work-about its monolithic approach to montage, its systematic cataloguing and reduction of the "effet cinéma" to one singular mode of organization. Some of the films, video essays, and installations mentioned in the course of this discussion (Varda's Les Glaneurs, Godard's Histoire(s), Claudio Pazienza’s Archipels Nitrate, and Kentridge's The Refusal of Time) are exemplary in the way they use montage 
and collage to undermine established epistemologies and create formally and thematically disruptive connections. Marclay's serial sampling, on the other hand, creates a closed system that runs itself. Where one approach points to the endless possibilities, formal as well as critical, of appropriation and montage, Marclay's method focuses on compilation as taxonomy and, with dazzling virtuosity, points to its own limits.

Martine Beugnet is professor in visual studies at the University of Paris 7 Diderot. She has written articles and essays on a wide range of film and media topics, and has published four books: Sexualité, marginalité, contrôle: cinéma français contemporain (L'Harmattan, 2000), Claire Denis (M.U.P, 2004), Proust at the Movies (Ashgate, 2005) together with Marion Schmid, and Cinema and Sensation: French Film and the Art of Transgression (Edinburgh University Press, 2007 and 2012). She also co-directs, together with Kriss Ravetto, a book series in film studies at E.U.P. Martine Beugnet, martine.beugnet@univ-parisdiderot.fr

\section{NOTES}

1. Benjamin writes that film brings together "all the forms of perception, the tempos, the rhythms which lie preformed in today's machines." Walter Benjamin, The Arcades Project, trans. Howard Eiland and Kevin McLaughlin (Cambridge, Mass. and London: Harvard University Press, 1999), 394.

2. Peter Osborne, "Distracted Reception: Time, Art, and Technology," in Time Zones: Recent Film and Video, eds. Jessica Morgan and Gregor Muir (London: Tate Publishing, 2004), 70.

3. Osborne, 66-75.

4. See for example, Luc Vancheri, Cinémas contemporains, Du film à l'installation (Lyon: Aléas, 2009), as well as the polemical manifesto by Philippe Dubois, "Oui, c'est du cinéma," which is a far cry from his previous writing on the effet cinéma: 'Oui, c'est du cinéma. Formes et espaces de l'image en mouvement" (Pasian di Prato: Companatto Editore, 2009), 7-10.

5. Dubois writes of an 'effet cinéma' dans tous les cas extrêmement diversifié et multiforme. Un 'effet cinéma' qui opère à tous les niveaux: au plan institutionnel, au plan artistique, et au plan théorique (ou critique)." "Le cinéma informe, nourrit, influence, travaille, inspire, irrigue." Philippe Dubois, "L’Effet cinéma," Cinema and Cie (no. 8, 2006): 15-26. Here, the French expression "effet cinéma" is initially used to distinguish it from the title of Sean Cubitt's book, The Cinema Effect (Cambridge, Mass.: MIT, 2003). See also Raymond Bellour, La Querelle des Dispositifs (Paris: POL \& Trafic, 2012).

6. Walter Benjamin, "Theses on the Philosophy of History," Illuminations, trans. Harry Zohn, ed. Hannah Arendt (New York: Schocken, 1968), 262.

7. Béatrice Hanssen, ed., Benjamin and the Arcades project (London: Continuum, 2006), 135.

8. Photography, rather than film, is central to Malraux's conception of the musée imaginaire, 
where the compilation of art reproductions emulate and sustain human imagination by bringing together art works regardless of their temporal and geographical origins. André Malraux, The Psychology of Art, Vol. I: Museum Without Walls (New York: Pantheon Books, 1949).

9. Concerned with cinema itself, or with art more generally, in film and video form, JeanLuc Godard's Histoire(s) du cinéma (1998), Agnès Varda’s Les Glaneurs et la Glaneuses (The Gleaners and I, FR, 2000), and Claudio Pazienza’s Archipels Nitrate (FR, 2010) offer characteristic examples of "strategic poetic montage" employed to create "imaginary museums" that take into account the images' historical context of production.

10. Jay Leyda, Films Beget Films: A Study of the Compilation Film (New York: Hill and Wang, 1964).

11. Both Emma Cocker (based on the Tate Modern's 2006 exhibition "Anticipating the PastArtists: Archive: Film") and Philippe Dubois offer useful sets of categories distinguishing between a diversity of found footage, compilation, and citation techniques. Emma Cocker, "Ethical Possession: Borrowing from the Archives," Scope (17, 2010), www.scope.nottingham .ac.uk/cultborr/chapter.php?id=9, accessed Feb. 4, 2013. Dubois, "L'Effet cinéma," 2006.

12. Girardet's 60 Seconds (AU, 2003), which shows a succession of sixty different clocks in one minute, stands as a forerunner to Marclay's The Clock. Although it is also focused on classic Hollywood, Martin Arnold's work is not cited here because it does not rely on serial compilation as such.

13. Tracey Moffatt and Gary Hillberg, Lip (US, 1999), and Love (2003).

14. Philip Monk, 'Paint it black: Curating the Temporal Image', in Projecting Questions? Mike Hoolboom's Invisible Man between the art gallery and the movie theatre (Toronto: Art Gallery of York University, 2009), 30. Laura Mulvey further notes how "as the cinema ages, it acquires greater cultural legitimacy and the divide between art and popular film has narrowed almost into invisibility." Death $24 x$ a Second: Stillness and the Moving Image (London: Reaktion Books, 2006), 29.

15. The trailer is preceded by an announcement outlining Marclay's "fragment technique," working "through 70 years of film history." www.youtube.com/watch?v=xp4EUryS6ac, accessed March 23, 2013.

16. Thanks to Tyler Parks for pointing out to me the import of seeing The Clock "after hours," as it were.

17. See for instance Peter Bradshaw's review of the piece for the Guardian entitled "Christian Marclay's The Clock: A Masterpiece for our Times," www.guardian.co.uk/film/filmblog/2011/ apr/07/christian-marclay-the-clock, accessed March 23, 2013.

18. Jonathan Romney, “What Time is it Where?" Sight and Sound (21, no. 5, 2011):30. See also Rosalind Krauss, “Clock Time," October (136, Spring 2011): 213-17.

19. Romney, 31.

20. Sylviane Agacinski, "Western Time," Time Zones (London: Tate Publishing, 2004), 56-61.

21. Doane reminds us how early cinema was seen as a "sensitive indicator" of modern life, but 
one that "refuses the depth of experiential meaning." She says: "[time's] division into discrete entities—seconds, minutes, hours, and its regulation by the clock ... is a symptom of the foreclosure of meaning... Rationalization supplants, displaces, or, in a sense, mimics meaning." The Emergence of Cinematic Time (Cambridge, Mass., and London, 2002), 14.

22. See the useful distinction established by Jonathan Walley between (low budget and largely self-made) experimental films and (higher budget, technically assisted, and editioned) artists' films. "Modes of Film Practice in the Avant-Garde," Art and the Moving Image, ed. Tanya Leighton (London: Tate, 2008), 182-99.

23. Indeed, the project is not unlike the kind of so-called "creative" reels traditionally compiled by advertising agencies: series of extracts from films on specific topics to be used as reference or "inspiration" for future commercials.

24. The iPhone ad, an obvious imitation of Marclay's original piece, can be seen on http:// radaronline.com/exclusives/2008/10/artist-says-iphone-ad-was-a-ripoff-php/, accessed March 23, 2013. See also Daniel Zalewski, “The Hours: How Christian Marclay created the ultimate digital mosaic," The New Yorker (March 12, 2012): www.newyorker.com/ reporting/2012/03/12/120312fa_fact_zalewski, accessed March 23, 2013.

25. Romney, 30.

26. As Victor Burgin has noted, in terms of narrative forms, techniques once received as avantgarde rejections of classical realist cinema are now part of routine computer practices. Victor Burgin, The Remembered Film (London, Reaktion Books, 2004), 14.

27. Amongst other films, Jacobs talks about Jean-Luc Godard's Bande à part (FR, 1964), with its famous sequence of the full Louvre visit in less than 10 minutes. Steven Jacobs, Framing Pictures: Film and the Visual Arts (Edinburgh: Edinburgh University Press, 2010), 72-73. The quote is from a conference paper, parts of which are published in the book.

28. Catherine Fowler, "Room for Experiment: Gallery Films and Vertical Time from Maya Deren to Eija Liisa Ahtila," Screen 45, no. 4 (2004): 324-43.

29. Catherine Elwes, 'Starting a Conversation About ... Artists' Film, Video and Installation," Filmwaves, vol 14, no.1 (2001): 46-47.

30. See for instance Richard Rushton, "Deleuzian Spectatorship," Screen 50, no.1 (2009): 45-53. Raymond Bellour, “The Cinema Spectator: A Special Memory," Audiences, ed. Ian Christie (Amsterdam: Amsterdam University Press, 2012), 206-18.

31. Mike Hoolboom, interview, Projecting Questions (2004), 45.

32. According to the Paula Cooper Gallery Press handout, it has been described as a "magnificent work" (The Guardian) and "relentless and compelling," "utterly transfixing" (The Huffington Post), www.paulacoopergallery.com/exhibitions/497, accessed March 23, 2013.

33. Krauss, “Clock Time," 215.

34. Krauss, "Clock Time," 216.

35. Rosalind Krauss, "The Cultural Logic of the Late Capitalist Museum," October (54, Autumn, 1990): 3-17. Theodor Adorno, “Correspondence with Benjamin," trans. Harry Zorn, New 
Left Review (1973), 55-79.

36. Krauss, "Clock Time." See also: Rosalind Krauss, "The Guarantee of the Medium” (Collegium, 5, 2009): 139-45.

37. Walley, "Modes of Film Practice."

38. Hal Foster, "The Archival Impulse" (October 110, 2004): 3-22.

39. Cocker, "Ethical Possession: Borrowing from the Archives" (2010).

40. Jan Verwoert, "Living with Ghosts: From Appropriation to Invocation," Art and Research, Vol 1, no. 2 (2007): www.artandresearch.org.uk/v1n2/verwoert.html, accessed Feb. 4, 2013. 